\title{
The Choice of Methods of Quarry Wastewater Purifying
}

\author{
Yury Lesin ${ }^{1, *}$, Vyacheslav Gogolin ${ }^{1}$, Elena Murko ${ }^{1}$, Sergey Markov ${ }^{1}$, and Jurgen \\ Kretschmann ${ }^{2}$ \\ ${ }^{1}$ T.F. Gorbachev Kuzbass State Technical University, Underground Mining Department, 650000 \\ Kemerovo, 28 Vesennya st., Russian Federation \\ ${ }^{2}$ Technische Hochschule Georg Agricola (THGA), Bochum, Germany
}

\begin{abstract}
The negative effect made by mining enterprises on the natural environment has complex origination. The intensive pollution is observed because of the influence of mineral deposits open-pit mining on the atmosphere, water resources and landscape complexes. Complex processes of environmental anthropogenic changes caused by open pits' operations have brought to light the problem of surface water pollution near large mining segments. Industrial wastewater of mining enterprises has a significant impact on the natural environment. In connection with the continuous and significant increase in the volume of mining, the amount of wastewater from mines, quarries and processing plants is constantly increasing. The main components of wastewater from operating mining enterprises are mine (quarry) waters, as well as runoff from atmospheric waters polluted by water erosion of dumps and mineral stacks. The paper describes the possible ways of quarry wastewater purifying - using hydrocyclones and artificial filtering arrays made from overburden rock.
\end{abstract}

\section{Introduction}

The main constituent of mine (quarry) waters are the waters coming from aquifers (the underground origin of water) and from the surface (atmospheric waters). The amount of these waters can be very different. Often, especially in coal mines, the amount of accompanying water rises sharply due to sudden breakthroughs of water from aquifers, from previously dumped workings and surface water bodies, as well as through flood and stormwater breakouts. Contamination of the water depends on the properties of the strata of rocks intersected by the wells. The initial contamination is mainly determined by the degree of mineralization of the waters of the underground horizons, as well as suspended particles of surface and groundwater.

Technological waters, which volume is relatively low in traditional methods of underground mining (rarely exceeds $10 \%$ of the total volume of mine waters), are contaminated with fine dispersed mineral particles and chemical solutions used in drilling wells, as well as in dust suppression. For mineral deposits open-pit mining, the amount of

\footnotetext{
*Corresponding author: 1yuv.geo@kuzstu.ru
} 
associated water is determined by the water cut of the rocks and by atmospheric precipitation. In many cases, the amount of these waters is considerable, which complicates the carrying out of mining operations. To counter them, first the various drainage measures are carried out. During the construction of quarries, drainage costs often amount to $20-30 \%$ of the total cost of mineral deposits open-pit mining. The main sources of water pollution include the masses of destroyed rock and minerals in the faces, the internal dumps of overburden and the erosive surface of the side (especially non-working) of the quarry.

Technological waters in the open-pit mining of ore, coal and non-metallic deposits are used in moderate quantities for drilling wells, dust suppression and in significant quantities for hydro-mining and hydrotransport.

Waters, flowing from external rock dumps and from dumps of substandard minerals, in relatively small quantities enter the quarry through the sides. Industrial sewage of mining enterprises can be characterized by high acidity, alkalinity, salinity, stiffness and turbidity. They are contaminated with solid and colloidal particles of rocks and minerals; various chemical compounds; contain organic and bacterial contaminants [1-2]. Expanding the use of self-propelled equipment in underground excavations, and in open-pit mines - a powerful transport and technological equipment with diesel engines [3-4], has led to an increase in the pollution of mine and quarry waters with oil products.

\section{Materials and Methods}

Organic pollution of quarry water is represented by phenols and petroleum products. The maintenance of phenols is usually small $-0.001-0.01 \mathrm{mg} / \mathrm{l}$. The sources of phenolic contamination on coal open pits are the processes of oxidation and self-ignition of coals, combustible materials when they enter the water. The content of petroleum products also varies within very wide limits $-0.01-13 \mathrm{mg} / \mathrm{l}$. In some cases, the content of trace elements is also exceeded: for cadmium in 3-11 times, for nickel in 2-18 times, for copper in 10-20 times, for zinc in 2-200 times, for chromium in 5-123 times, for cobalt in 2-27 times, for manganese in 2-200 times. Bacterial contamination of quarry water also varies within very wide limits, and its coliform index ranges from 1104 to 1107 [1].

The most significant (quantitatively and qualitatively) sources of water pollution in mining industry are mineral processing plants, tailing dumps, sludge dumps, evaporators and other industrial facilities. For example, during the ore enrichment, the content of iron and nitrite ions $\left(\mathrm{NO}_{3}\right)$ increases not only in factory water, but also in tailing water. The filtration losses of water will result in groundwater contamination, where three zones of groundwater flow to the tailing dumps are formed:

1. Zone closest to the tailing dump, where the concentration of $\mathrm{NO}_{3}$ and other components in the groundwater is equal to their content in the waters of the tailing dump. The maximum radii of this zone vary from 2500 to $4500 \mathrm{~m}$ in the direction of quarry drainage systems, and for the other directions it does not exceed $1500 \mathrm{~m}$.

2. Zone, where the content of nitrate ions is less than in the tailings, has the radius of 240$800 \mathrm{~m}$.

3. Zone, where the nitrite ions content is equal to zero. It is located at an average distance of 1800-2200 m, and in the directions to quarries - at the distance of $5000 \mathrm{~m}$.

In the tailings of the processing factories of ores of non-ferrous metals, there are pollutants such as arsenic, zinc, lead, cyanides, etc.

In wastewaters of coal-preparation plants, in addition to solid particles, dissolved mineral salts are also presented - chlorides, nitrates, nitrites, sulfates, carbonates, etc. In addition, they contain residues of flotation agents that are partially dissolved in water, partially sorbed on suspended solids. In addition to quarry and process wastewater, the atmospheric (storm 
water) causes considerable damage to the natural environment. This water wash out and carry out many polluting and harmful substances [5-6].

The inflow of atmospheric water into the quarry $\left(W_{a}, \mathrm{~m}^{3}\right)$ is determined by the following formula:

$$
W_{a}=8 H_{b c} \times k_{1} \times F+25 H_{O} \times k_{2} \times F
$$

$H_{B C}$ - the average height of the stream layer, $\mathrm{m} ; F$ - the area of atmospheric water collecting, hectares; $H_{O}$ - mean annual rainfall, $\mathrm{mm} ; k_{1}, k_{2}$ - the rates considering the volume of rain and snow-melting water, channeled to water treatment facilities.

The main pollutants of atmospheric water at open-pits are suspended substances (from 300 to $30000 \mathrm{mg} / \mathrm{l}$ ), petroleum products (up to $5000 \mathrm{mg} / \mathrm{l}$ ), phenols (up to $0.1 \mathrm{mg} / \mathrm{l}$ ), and the mineralization is $200-3500 \mathrm{mg} / \mathrm{l}$. The content of suspended solids in rainwater draining from dumps of coal open pits reaches $11700 \mathrm{mg} / \mathrm{l}$, in snow-melted water - $47000 \mathrm{mg} / \mathrm{l}$, and the total salt content is $7550 \mathrm{mg} / \mathrm{l}$. Surface wastewater contains mainly suspended substances (up to $2500 \mathrm{mg} / \mathrm{l}$ ), mineral salts (up to $5000 \mathrm{mg} / \mathrm{l}$ ) and petroleum products (up to $75 \mathrm{mg} / \mathrm{l}$ ). The content of organic substances in comparison with sewage household waters is relatively low $(100-150 \mathrm{mg} / \mathrm{l})$. The average volume of surface runoff is $2.6-4.0$ thousand $\mathrm{m}^{3} /$ year from one hectare of the quarry field.

\section{Results and Discussion}

The construction of mining enterprises is usually accompanied by not very large changes in water regimes caused by reclamation on the surface (in particular, drainage of the riverbed or stream), dewatering, carried out mainly to facilitate tunneling work, and pumping out the waters entering the workings. At the beginning and furthermore - for the development of mining operations, the scale of changes in water regimes is increasing. Groundwater in large or small quantities is released to the surface, changing the water regime in mining area, which leads to negative environmental consequences.

The most significant changes in hydrogeological conditions are observed in the construction of quarries. Therefore, before the beginning and during the development of mining operations, some measures must be taken to drain the rock massifs [7-8].

The simplest dehumidifying measure is "open water drainage", in which the water entering the workings along the drainage ditches or trenches flows into the water ponds and is pumped out the quarry field. With significant water content of rocks with high water permeability, dewatering wells are widely used, equipped with submersible pumps.

Measures to reduce the negative consequences associated with the of contaminated water inflow from exploratory wells and excavations, are divided into preventive and radical.

Preventive measures are aimed at reducing contaminated water inflow by constructing drainage barriers from water-absorbing materials and dewatering well systems; devices of anti-filtration curtains, which are waterproof or weakly permeable fences. Installed around the facility along the entire depth to the waterproof horizons, they help to prevent contaminated water penetration in the streams and rivers. Reduction of water inflows into excavations also means preventing the penetration of surface water into open pits.

Radical measures consist in the purification of quarry and underground mine wastewater and its maximum use in a closed cycle for mining needs.

Let us consider the processes and technical means of improving the quality of sewage of mining enterprises.

Quarry wastewater purification is achieved by settling and filtering. Precipitation of suspended coarse mineral and rock particles begins at a certain fluid flow rate, but the most intensive purification is carried out in a stationary flow. Purification of wastewater is carried out in water-ponds of various designs, relatively small excavations, underground mine 
workings and peculiar ponds with the standing of water in them for 7-12 days. As a result of the action of solar radiation, the vital activity of fresh water aquaculture, the dilution by downfall from the atmosphere, the quarry wastewater is getting self-purified in these ponds.

To remove coarse particles the filtering substances like quartz sand, crushed gravel, etc. are widely used as a filtering material.

Finely dispersed and colloidal particles contained in quarry wastewater are not completely precipitated even in a still water and are not checked by the filters. Therefore, for purification purpose, small amounts of coagulants or flocculants are added to the water. The most commonly used coagulants include aluminum and iron hydrosulfates, iron chloride, iron vitriol, metallurgical waste products containing aluminum and iron salts in significant amounts. The flocculants also can be the water-soluble substances with high molecular weight, derived from plant raw materials (starch, cellulose), synthetic organic polymers (polyacrylamide), etc.

Acid quarry waters containing free mineral acid (most often sulfuric) are neutralized in the purification process by various reagents. The most commonly used calcium hydroxide (hydrated lime), limestone, dolomite, magnesite, chalk.

Quarry waters containing an increased amount of salts are desalinated by means of distillation and electrodialysis methods. However, nowadays, the desalination of quarry wastewater does not go beyond experimental research.

Disinfection of mine waters is carried out when strong oxidants are applied to bacterially contaminated water; they are usually chlorine, chlorine lime, sodium hypochlorite.

Chlorination is characterized by the availability of reagents, the reliability of their action, relatively low costs. The disinfecting effect of chlorine is described by the following reactions:

$$
\mathrm{Cl}_{2}+\mathrm{H}_{2} \mathrm{O}=\mathrm{HOCl}+\mathrm{HCl} ; \mathrm{HOCl}=\mathrm{H}^{+}+\mathrm{OCl}^{-} ; \mathrm{HOCl}=\mathrm{HCl}+\mathrm{O}
$$

Thus, when water is chlorinated, wastewater is treated as a result of the action of chlorine, hypochlorous acid, hypochlorite ion and atomic oxygen. But this method has a number of drawbacks: toxicity of chlorine, deterioration of the organoleptic properties of water, ineffectiveness of chlorine to spore-forming bacteria, the possibility of formation of chlorinecontaining organic compounds.

Disadvantages of the chlorination method of disinfection inspire to use bactericidal rays of argon-mercury lamps or mercury-quartz lamps, which are installed over water or immersed in it. The method is applicable for a concentration of suspensions of less than 3 $\mathrm{mg} / \mathrm{l}$. Ozonation has recently become more common.

Cleaning of mine waters is carried out both in underground workings and on the surface. For underground conditions, it is expedient to use hydrocyclones (Fig. 1 and 2). High efficiency, simple design, small dimensions and cost ensure the efficiency of their application for the primary cleaning of mine water.

For ore and coal deposits open pit mining, the measures to purify the quarry water are similar to those described, but are characterized by large-scale activities.

Overburden rock dumps located near the quarries, when melting of snow or rain begins, as already mentioned, are sources of pollution of surface and underground waters (mainly groundwater). Atmospheric water, falling on the dump and draining from its lateral surfaces, is polluted by erosion of rocks, and when filtered through the rock mass, it becomes more or less mineralized.

Reducing the intensity of erosion processes can be achieved by choosing a certain ratio between the height of the bench and the slope angles, which determine the speed of water flowing from the dump. Reducing the infiltration of mineralized water into the soil is achieved by overlapping the base of the dumps (before dumping the overburden) with a layer of clay with a thickness of 1-1.5 m. It is advisable to channel accumulated wastewater using 
reclamation facilities to a centralized drain and direct them to the treatment facilities, in particular water basins or hydrocyclones [9].

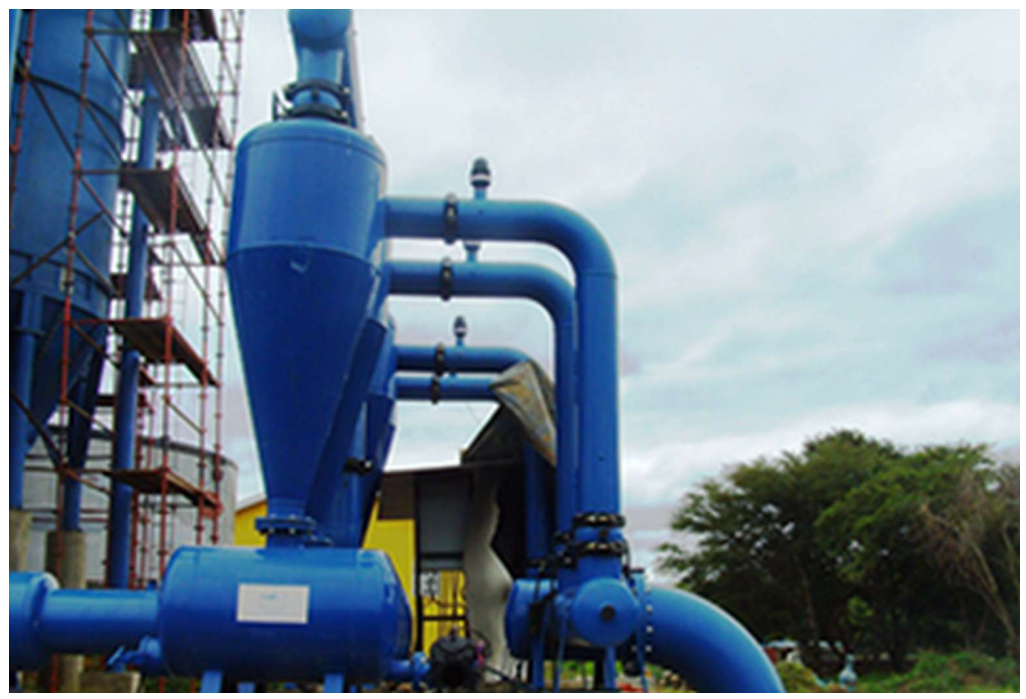

Fig. 1. The outside appearance of hydrocyclones.
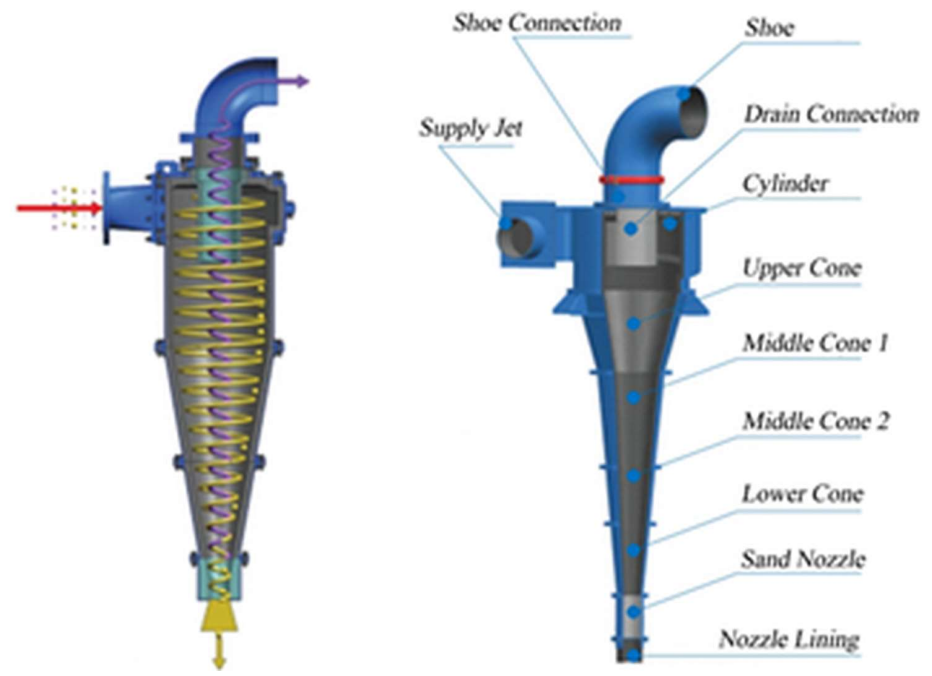

Fig. 2. The construction of hydrocyclone.

Currently the most common method of wastewater treatment on the open-pits is a mechanical purifying by clarification in settling ponds and filtration through arrays of overburden rocks.

Except specially piled rock arrays, already existing open-pit dumps can be also used as the filters.

For using waste dumps or any other similar arrays of rock in water purification schemes it is strictly necessary:

- to choose one or another particular dump (filtering array) and identify the ways of supplying and discharging water;

- to test the ability of the dump to pass all the clarified water at the given water disposal in the period of maximum flow; 
- to test the ability of the selected dump to clarify water to the maximum permissible concentration rates.

It is desirable to use both active and inactive truck and railway external dumps located near the water disposal. The content of the slacking rocks in the filtering array must not exceed $30 \%$. When choosing a dump the following issues should be observed: topography of the bedding surface in order to determine the most appropriate places of clarified water supply, the direction and length of the filter, the area of water seepage from the dump. Water may be supplied to the dump by gravity or by pumping. To avoid infiltration into the bed of the dump rock the bases should be low permeable.

"The core" of quarry wastewater purifying using artificial filtering arrays is the colmatation - the process of natural penetration or artificial insertion of small particles into rock's fractures (Fig. 3).

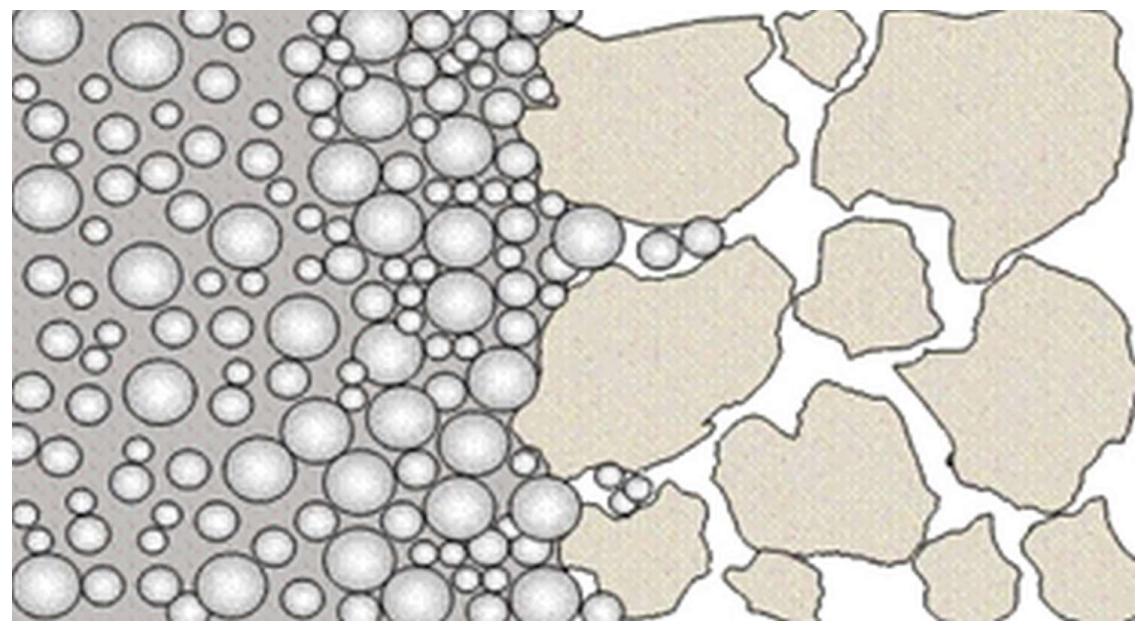

Fig. 3. The scheme of colmatation process.

The technical solution to the problem of wastewater treatment from suspended solids in the filters of coarse rocks can be searched in two ways. The first of them is to use the discrete rocks arrays existing at enterprises as filters after a preliminary examination. Such arrays include various technological dumps.

The second way is the purification of water in specially constructed filtering arrays of rocks and semi-rocks, which are, as a rule, the mining waste.

The filters' design depends on the terrain and the properties of the upper layers of the ground of the underlying surface, and the parameters are determined by the volume of water supply, its pollution density and filtration characteristics of the filtering material.

The main filter elements are the unit for supplying polluted water, filtering array, filter body, a device for collecting and draining the purified water. If there are any natural or artificial hollows (ravines, logs, river beds of dried-up rivers, trenches, ditches, abandoned mines and others) near the water disposal and low permeable rocks that lie at their sides and bottom, the latter can be the body of the filter, Figure 4. In this case, water may be supplied to the filter array by gravity on a surface or pipe and by pumping. The filter array is piled from rocks that meet the relevant requirements using trucks and bulldozers. 


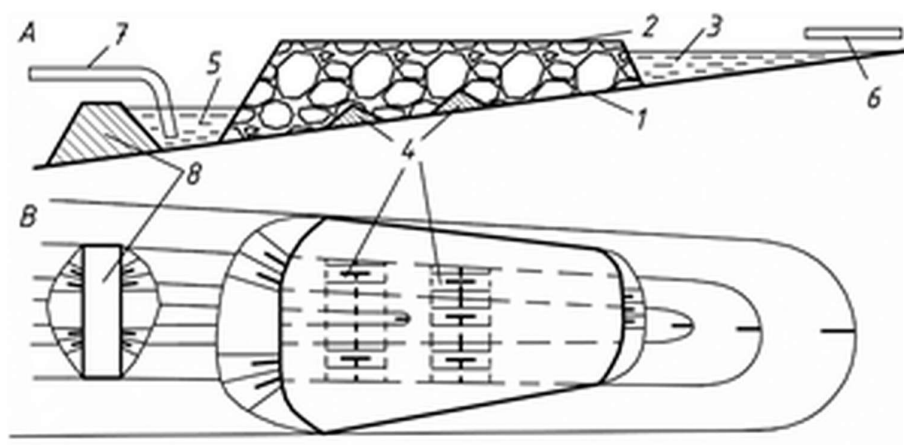

Fig. 4. Construction of the filtering array with waterproof stopping.

A) longitudinal section; B) plan view; 1) the bottom of the filter; 2) filtering array; 3) receiver for contaminated water; 4) waterproof stopping; 5) lodgement of purified water; 6) conduit for feeding of contaminated water; 7) conduit for purified water removing; 8) water retention levee.

The filter body is a water-holding dam, piled of rocks with low hydraulic permeability. For supplying purified water to the filter array at one of its ends with the help of the dam a container is formed. Water reservoir with purified water is a pit created by the excavators and bulldozers at the base of the filter at the filter array open end. The movement of water in the filter is carried out by the pressure created by a column of water in the receptacle. The purified water is pumped from the water reservoir, and supplied to water bodies' spillage or to meet the needs of the enterprise.

\section{Conclusion}

In the article, two ways of cleaning the quarry waters - the use of special devices (hydrocyclones) and artificial filtering arrays - were considered. Despite significant differences in the complexity of their designs, the need for their application is due to the importance of improving the environmental level of open mining. It is assumed that artificial filtering arrays should be used for initial treatment of quarry wastewaters, and hydro-cyclones - for fine cleaning.

\section{References}

1. M. Tyulenev, Y. Lesin, E. Tyuleneva, E. Murko, E3S Web of Conferences, 15, 02003 (2017)

2. M. Tyulenev, Y. Lesin, O. Litvin, E. Maliukhina, A. Abay, E3S Web of Conferences, 21, 02019 (2017)

3. V. Kolesnikov, O. Litvin, J. Janočko, A. Efremenkov, E3S Web of Conferences, 21, 01031 (2017)

4. N. Demirel, S. Frimpong, International Journal of Mining, Reclamation and Environment, 23:1, 4-20 (2009)

5. S. Markov, V. Martyanov, E. Preis, A. Abay, E3S Web of Conferences, 21, 01021 (2017)

6. S. Markov, M. Tyulenev, O. Litvin, E. Tyuleneva, E3S Web of Conferences, 15, 01011 (2017)

7. M. Prekopová, J. Janočko, V. Budinský, M. Friedmannová, Environmental Earth Sciences, 76:1, 25 (2017) 
8. B. Sály, J. Janocko, S. Jacko, V. Jureňa, I. Hlavaty, New results in the mature east slovakian basin based on $3 D$ and $2 D$ seismic data interpretation and sequence stratigraphy, Society of Petroleum Engineers, 68th European Association of Geoscientists and Engineers Conference and Exhibition, incorporating SPE EUROPEC 2006 (EAGE, 2006)

9. S. Zhironkin, M. Gasanov, G. Barysheva, K. Kolotov, O. Zhironkina, E3S Web of Conferences, 15, 03012 (2017)

10. S. O. Markov, M. A. Tyulenev, E. G. Kuzin, Journal of Mining and Geotechnical Engineering, 1, 56-63 (2018) DOI: 10.26730/2618-7434-2018-1-56-63 